\title{
Frequency of puerperal infection with meconium stained amniotic fluid.
}

\author{
DR. HUMA JAVAID, MBBS \\ NISHTAR HOSPITAL, MULTAN, PAKISTAN. \\ DR. MARIA TARIQ, MBBS \\ NISHTAR HOSPITAL, MULTAN, PAKISTAN.
}

DR. MIAN AAMIR FIAZ, MBBS

MEDICAL OFFICER, DHQ HOSPITAL, MUZAFFAR GARH, PAKISTAN.

\begin{abstract}
;
Objective: To determine the association of meconium stained amniotic fluid with puerperal infection. Material, place and method: A Cohort Study was conducted from $1^{\text {stjanuary }} 2018$ to $30^{\text {th }}$ June 2018 in department of obstetrics \& gynecology, Nishtar hospital, Multan. A total of 66 women with singleton pregnancy, gestational age 37-41 weeks of any parity undergoing elective caesarean section were eligible in study. Patients with rupture of membranes for more than 6 hours on history, diabetic patients, preterm delivery and post term delivery were excluded. During elective caesarean section, after rupture of membranes women were divided in two equal groups. $33(50 \%)$ patients with meconium stained liquor in exposed group and 33 patients $(50 \%)$ with clear liquor in un-exposed group were divided. Puerperal infection was noted when temperature of $38^{\circ} \mathrm{C}$ and higher on any two of first ten days postpartum excluding of first 24 hours. The data was analyzed using statistical analysis program to compare proportions between these two groups. Frequency, percentage and mean $\pm \mathrm{SD}$ were presented for variables. Chi-square test was applied to compare puerperal infection in both groups taken $\mathrm{p} \leq 0.05$ as significant. Results: Age range in this study was from 18 to 35 years with mean age of $28.000 \pm 2.27$ years in Exposed Group while 26.212 3.06 years in Unexposed Group. Mean gestational age was $38.848 \pm 1.12$ weeks in exposed group while $39.060 \pm 1.11$ weeks in unexposed group. Puerperal infection was seen in $63.64 \%$ patients in exposed Group as compare to $12.1 \%$ in unexposed Group $(\mathrm{p}=0.005)$. Conclusion: Recognition of the increased risk of infection in women with meconium stained fluid improves the perinatal outcome.
\end{abstract}

Keywords: Meconium stained amniotic fluid, Puerperal infection, Association, cohort study.

DOI: $10.7176 / \mathrm{JMPB} / 54-17$

Publication date: April $30^{\text {th }} 2019$

Introduction:

Meconium stained amniotic fluid is seen as a result of release of fetal meconium into the amniotic fluid. ${ }^{1}$ The prevalence of meconium passage into the amniotic fluid is $19 \%^{2}$ and $16.97 \%{ }^{3}$, however, this condition is rare in preterm pregnancies and patients undergoing elective cesarean section and is more common in pregnancies after 40 weeks, longer duration of labour and prolong ruptures of membranes. Meconium-stained amniotic fluid represents a fetal response to stress and is associated with non-reassuring fetal heart trace and low Apgar scores 3,4. The operative obstetrics inform of cesarean section and operative vaginal delivery are almost double in deliveries complicated by meconium-stained amniotic fluid ${ }^{3}$. Aspiration of meconium may result in the increase in perinatal mortality and morbidity especially in post term pregnancy ${ }^{5}$. Alexander observed that meconium stained amniotic fluid is 1.5 times more common in blacks than whites ${ }^{6}$. Meconium stained liquor aspiration is the most common cause of persistent pulmonary hypertension of the newborns ${ }^{7}$.

The meconium-stained amniotic fluid is not only carries the risks to the newborn but retains the capacity of increase maternal complications. Clinical choriamnionitis and funisitis is higher in meconium-stained amniotic fluid at birth ${ }^{8}$. Many microorganisms are isolated from the amniotic fluid cultivation in meconium-stained amniotic fluid which carry a risk of infection for both mother and baby. ${ }^{9}$ The maternal lower genital tract is the main source for these bacteria. Pregnant women who had meconium-stained amniotic fluid had increased risk for peripartum and postpartum infection due to endometritis. ${ }^{10}$ The incidence of clinical chorioamnionitis is significantly higher in the presence of severe than mild meconium stained liquor. ${ }^{10}$ Among women in preterm labor, the prevalence of positive amniotic fluid cultures after amniocentesis is significantly higher in those with meconium stained liquor compared to those with clear fluid. ${ }^{11}$ Adair and colleagues ${ }^{12}$ reported a randomized trial of intrapartum antibiotic administration in pregnancies complicated by meconium-stained amniotic fluid to reduce endometritis, they concluded that intrapartum antibiotic administration reduced intra-amniotic infection in women with meconium-stained fluid. Although antibiotic administration may reduce the risk of infection associated with meconium-stained fluid, there is no current intervention to reduce meconium passage, so 
primarily prevention efforts must focus on other issues. Treatment of vaginal infections before labor, as well as the limitation of vaginal examinations and internal monitoring in labor may reduce the peripartum infection rate. Cesarean delivery, as the most influential independent risk factor for postpartum infection, should be avoided if possible. If cesarean delivery is required, prophylactic antibiotics should be given intraoperatively. Intrapartum antibiotic administration may reduce peripartum infection in women with meconium- stained amniotic fluid undergoing cesarean section.

No such study has been done before in our general population. One study showed the presence of meconium in the amniotic fluid as one of the risk factors for infection in the postpartum period due to endometritis. ${ }^{12,13}$ On the contrary other study showed no difference of infection between meconium stained amniotic fluid as compare to clear amniotic fluid in pregnancy ${ }^{14}$. Therefore it is necessary to get local data on this topic by determining the association of meconium stained amniotic fluid with puerperal infection after delivery in our general population. My study will pave the way for proper management of meconium stained amniotic fluid during pregnancy to minimize the morbidity in women after delivery.

Methodology: A Cohort Study was conducted from $1^{\text {st }}$ janauary 2018 to $30^{\text {th }}$ June 2018 in obstetrics \& gynecology department, Nishtar Hospital, Multan. The non-probability consecutive sampling was used and included total 66 patients, 33 patients in exposed Group or meconium stained amniotic fluid group and 33 patients in un-exposed group or clear amniotic fluid group after the rupture of membranes during cesarean section. This study included women with singleton pregnancy, gestational age 37-41 weeks of any parity undergoing elective caesarean section. Patients with rupture of membranes for more than 6 hours on history, diabetic patients, preterm delivery and post term delivery were excluded. The permission from ethical committee of the hospital was obtained. A detailed explanation about the participation in the study was given to the patient and a written informed consent was obtained explaining the benefits of the study. Patients were evaluated and basic demographics like age, gestational age and paritywere noted. During elective caesarean section, after rupture of membranes women were divided in two equal groups. Thirty three (n-33) patients for exposed group and 33 patients for un-exposed group on the basis of amniotic fluid. Caesarean sections were done by a consultant gynecologist of 3 years post fellow ship experience. All the mothers received intravenous ceftriaxone half an hour before the surgeryuntil 48 hours after the surgery. Puerperal infection was noted when temperature of $38^{\circ} \mathrm{C}$ and higher on any two of first ten days postpartum exclusive of first 24 hours. Data was collected for puerperal infection from both groups. The data was analyzed with statistical analysis program (IBM-SPSS-V21). Analysis was done to compare proportions between these two groups. Frequency and percentage was computed for qualitative variables like parity, meconium stained fluid grade and puerperal infection. Mean $\pm \mathrm{SD}$ was presented for quantitative variables like age and gestational age. Chi-square test was applied to compare puerperal infection in both groups taken $\mathrm{p} \leq 0.05$ as significant. Stratification of meconium stained fluid grades to puerperal infection were observed and chi-square test was applied, $p \leq 0.05$ was considered statistically significant.

\section{Results:}

Age range in this study was from 18 to 35 years with mean age of $28.000 \pm 2.27$ years in exposed Group while $26.212 \pm 3.06$ years in unexposed Group. Mean gestational age was $38.848 \pm 1.12$ weeks in exposed group while $39.060 \pm 1.11$ weeks in unexposed group as shown ( Table-1). Frequency and Percentage of parity (Table -2) and meconium stained fluid grades in exposed group are shown (Table-3). Puerperal infection was seen in $63.64 \%$ patients in exposed Group as compare to $12.1 \%$ in unexposed Group ( $\mathrm{p}=0.002$ ) as shown in Table-4. Stratification of Puerperal infection in exposed groups with regard to meconium stained amniotic fluid grades are shown in table-5. 
Table- I: Mean \pm SD of patients according to age and gestational age (n-66)

\begin{tabular}{|c|c|c|}
\hline Demographics & $\begin{array}{c}\text { Mean } \pm \text { SD } \\
\text { Exposed group } \\
n=33 \\
\end{array}$ & $\begin{array}{c}\text { Mean } \pm \text { SD } \\
\text { Unexposed group } \\
\mathbf{n}=\mathbf{3 3} \\
\end{array}$ \\
\hline Age(years) & $28.000 \pm 2.27$ & $26.212 \pm 3.06$ \\
\hline $\begin{array}{c}\text { Gestational age } \\
\text { (weeks) }\end{array}$ & $38.848 \pm 1.12$ & $39.060 \pm 1.11$ \\
\hline
\end{tabular}

Table-2: Frequency and Percentage of parity in both groups (n-66)

\begin{tabular}{|c|c|c|c|}
\hline \multicolumn{2}{|c|}{ Parity } & $\begin{array}{c}\text { Exposed group } \\
\mathbf{n = 3 3}\end{array}$ & $\begin{array}{c}\text { Unexposed group } \\
\mathbf{n}=\mathbf{3 3}\end{array}$ \\
\hline & $\mathbf{0 - 2}$ & $28(84.8 \%)$ & $29(87.9 \%)$ \\
\hline & $\mathbf{3 - 5}$ & $5(15.2 \%)$ & $4(12.1 \%)$ \\
\hline & Total & $33(100 \%)$ & $33(100 \%)$ \\
\hline
\end{tabular}

Table- 3: Frequency and percentage of patients according to meconium stained fluid grade in exposed group (n-33)

\begin{tabular}{|c|c|c|c|}
\hline \multicolumn{2}{|c|}{$\begin{array}{c}\text { Meconium stained fluid } \\
\text { grade }\end{array}$} & $\begin{array}{c}\text { No of } \\
\text { Patients }\end{array}$ & \%age \\
\hline & I & 6 & $18.2 \%$ \\
\hline II & 19 & $57.6 \%$ \\
\hline III & 8 & $24.2 \%$ \\
\hline Total & 33 & $100 \%$ \\
\hline
\end{tabular}

Table-4: Comparison of puerperal infection in both groups (n-66)

\begin{tabular}{|c|c|c|c|c|c|}
\hline \multicolumn{2}{|c|}{$\begin{array}{c}\text { Puerperal } \\
\text { infection }\end{array}$} & $\begin{array}{c}\text { Exposed group } \\
\mathbf{n = 3 3}\end{array}$ & $\begin{array}{c}\text { Unexposed group } \\
\mathbf{n = 3 3}\end{array}$ & total & \multirow{2}{*}{ P Value } \\
\hline & Yes & $21(63.64 \%)$ & $4(12.1 \%)$ & $25(37.9 \%)$ & \multirow{2}{*}{0.005} \\
\hline & No & $12(36.36 \%)$ & $29(87.9 \%)$ & $41(62.1 \%)$ & \\
\hline & Total & $33(100 \%)$ & $33(100 \%)$ & $66(100 \%)$ & \\
\hline
\end{tabular}


Table-5: Stratification of puerperal infection with respect to Meconium exposed group $(n=33)$.

stained fluid grade in

\begin{tabular}{|c|c|c|c|}
\hline \multirow{2}{*}{$\begin{array}{c}\text { Meconium stained fluid } \\
\text { grade }\end{array}$} & \multicolumn{2}{|c|}{ Puerperal infection } & \multirow[b]{2}{*}{ p-value } \\
\hline & Yes & No & \\
\hline 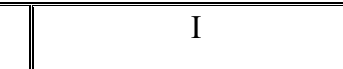 & $0(0 \%)$ & $6(100 \%)$ & \multirow{4}{*}{0.005} \\
\hline$\overline{\mathrm{III}}$ & $14(47.6 \%)$ & $5(52.4 \%)$ & \\
\hline IIII & $7(83.3 \%)$ & $1(16.7 \%)$ & \\
\hline Total & $21(63.64 \%)$ & $12(36.36 \%)$ & \\
\hline
\end{tabular}

\section{Discussion:}

The possibility of an association between meconium staining of the amniotic fluid and puerperal infection has been considered for many years. ${ }^{14,15}$ Observations in vitro, ${ }^{14}$ along with amniocenteses from preterm pregnancies ${ }^{16,17}$ and retrospective reviews of deliveries, ${ }^{18,19}$ have provided evidence to strengthen this potential association. The first publication analyzed the relationship between bacterial vaginosis and intra-amniotic infection. ${ }^{20}$ In that report, ${ }^{20}$ it was noted meconium-stained amniotic fluid to be more common in women with intra-amniotic infection than in those without. In our study, we document an association between meconium staining of the amniotic fluid and puerperal infection in a prospective cohort of laboring women who were enrolled upon admission for delivery and followed prospectively for development of intrapartum or postpartum infection. The key findings in our study were that 1) meconium stained amniotic fluid is associated with increased puerperal infection, independent of other risk factors for infection, and 2) thick meconium, in particular, is associated with marked increases in puerperal infectious morbidity. Our findings confirm those derived previously from retrospective reviews, with both intra-amniotic infection ${ }^{18,19}$ and postpartum infection mainly because of possibilities of endometritis ${ }^{19}$ occurring more frequently in pregnancies with meconiumstained fluid. Our rates of puerperal infection (63.64\% in exposed group and $12.1 \%$ in unexposed group) were compatible with the previously reported rates (6-33\% meconium, $0-11 \%$ clear) by Panichkul ${ }^{14}$ and previously reported rates of $18 \%$ vs $8 \%$ by Markovitz ${ }^{19}$ Wen and colleagues observed $8 \%$ vs $2 \%{ }^{18}$. Hamaideh compared endomyometritis in deliveries with clear amniotic fluid, those with meconium stained amniotic fluid found the higher rates of endomyometritis in meconium stained amniotic fluid (1.5 vs $3.2 \%){ }^{21}$ Their findings together with ours, emphasize the importance of recognizing meconium as an independent contributor to peripartum infection and need to develop strategies to diminish this risk.

Conclusion: In conclusion, recognition of the increased risk of infection in women with meconium stained fluid may improve perinatal outcome.

\section{References:}

1. Romero R, Yoon BH, Chaemsaithong P, Cortez J, Park CW, Gonzalez R, et al. Secreted phospholipase A2 is increased in meconium-stained amniotic fluid of term gestations: potential implications for the genesis of meconium aspiration syndrome. J Matern Fetal Neonatal Med. 2014;27(10):975-83.

2. Lee K, Lee S, Yang H. The frequency of meconium-stained amniotic fluid increases as a function of the duration of labor. J Matern Fetal Neonatal Med. 2011;24(7):880-5.

3. Mundhra R, Agarwal M. Fetal outcome in meconium stained deliveries. J ClinDiagn Res. 2013;7(12):2874-6.

4. Hernandez C, Little BB, Dax JS, Gilstrap LC, III, Rosenfeld CR. Prediction of the severity of meconium aspiration syndrome. Am J ObstetGynecol $1993 \mathrm{Jul} ; 169(1): 61-70$.

5.Galal M, Symonds I, Murray H, Petraglia F, Smith R. Postterm pregnancy. Facts Views Vis Obgyn. 2012;4(3):175-87.

6. Alexander GR, Hulsey TC, Robillard PY, De CF, Papiernik E. Determinants of meconium-stained amniotic fluid in term pregnancies. J Perinatol 1994 Jul;14(4):259-63.

7. bu-Osba YK. Treatment of persistent pulmonary hypertension of the newborn: update. Arch Dis Child 1991 Jan;66(1 Spec No):74-7. 1 
8.Seung Lee, MD, ${ }^{1}$ Romero R, Lee KA. The frequency and risk factors of funisitis and histologic chorioamnionitis in pregnant women at term who delivered after the spontaneous onset of labor. J Matern Fetal Neonatal Med. 2011 Jan; 24(1): 37-42.

9. Kim CJ, Romero R, Chaemsaithong P, Chaiyasit N, Yoon BH, Kim YM. Acute chorioamnionitis and funisitis: definition, pathologic features, and clinical significance. Am J Obstet Gynecol. 2015;213(4):S29-S52.

10. Piper JM, Newton ER, Berkus MD, Peairs WA. Meconium: a marker for peripartum infection. Obstet Gynecol. 1998;91(5 Pt 1):741-5.

11. Romero R, Espinoza J, Goncalves LF, Kusanovic JP, Friel LA, Nien JK. Inflammation in preterm and term labour and delivery. Semin Fetal Neonatal Med 2006 Oct;11(5):317-26.

12. Adair CD, Ernest JM, Sanchez-Ramos L, Burrus DR, Boles ML, Veille JC. Meconium-stained amniotic fluid-associated infectious morbidity: A randomized double-blind trial of ampicillinsulbactam prophylaxis. ObstetGynecol 1996;88:216 -9.

13. Tran SH, Caughey AB, Musci TJ. Meconium-stained amniotic fluid is associated with puerperal infections. Am J Obstet Gynecol. 2003;189(3):746-50.

14.Panichkul S ${ }^{1}$, Boonprasertmd K, Komolpismd S, Panichkul P, Caengow S.

The association between meconium-stained amniotic fluid and chorioamnionitis or endometritis. J Med Assoc Thai. 2007 Mar;90(3):442-7.

15. Florman AL, Teubner D. Enhancement of bacterial growth in amniotic fluid by meconium. J Pediatr 1969;74:111- 4.

16. Romero R, Hanaoka S, Mazor M, Athanassiadis AP, Callahan R, Hsu YC, et al. Meconium-stained amniotic fluid: A risk factor for microbial invasion of the amniotic cavity. Am J ObstetGynecol 1991;164:859-62.

17. Mazor M, Furman B, Wiznitzer A, Shoham-Vardi I, Cohen J, Ghezzi F. Maternal and perinatal outcome of patients with preterm labor and meconium-stained amniotic fluid. ObstetGynecol 1995; $86: 830-3$.

18. Wen TS, Eriksen NL, Blanco JD, Graham JM, Oshiro BT, Prieto JA. Association of clinical intraamniotic infection and meconium. Am J Perinatol 1993;10:438-40.

19. Markovitch O, Mazor M, Shoham-Vardi I, Chaim W, Leiberman JR, Glezerman M. Meconium stained amniotic fluid is associated with maternal infectious morbidity in preterm delivery. ActaObstetGynecolScand 1993;72:538-42.

20. Newton ER, Piper JM, Peairs WA. Bacterial vaginosis and intraamniotic infection. Am J ObstetGynecol 1997;176:672-7.

21. Hamideh P, Fatemeh M, Fatemeh R. Meconium Amniotic Fluid is Associated with Endomyometritis. J Obstet Gynaecol India. 2016 Oct; $66: 136-140$. 